\section{Check for updates}

Cite this: Chem. Sci., 2018, 9, 7370

¿ All publication charges for this article have been paid for by the Royal Society of Chemistry

Received 24th April 2018

Accepted 17th July 2018

DOI: $10.1039 / \mathrm{c} 8 \mathrm{sc} 01862 \mathrm{f}$

\title{
RAFT polymer cross-coupling with boronic acids $\uparrow$
}

\author{
Hartwig Golf, ${ }^{a}$ Riley O'Shea, ${ }^{a}$ Carl Braybrook, ${ }^{\text {b }}$ Oliver Hutt, ${ }^{\text {b }}$ David W. Lupton (D) *a \\ and Joel F. Hooper (D)*a
}

The ability to modify the thiocarbonylthio end-groups of RAFT polymers is important for applications where an inert or highly functionalised material is required. Here we report a copper promoted cross-coupling reaction between RAFT polymer end-groups and aryl boronic acids. This method gives high conversion to the modified polymers, and is compatible with a wide variety of functional molecules.

rsc.li/chemical-science

\section{Introduction}

Reversible addition fragmentation chain transfer (RAFT) polymerisation is a powerful method for the synthesis of narrow polydispersity polymers. ${ }^{1}$ Applicable to most monomers, RAFT is increasingly being deployed in sophisticated applications, such as in biomedical science. ${ }^{2-7}$ Central to such applications is the ability to prepare robust narrow dispersity polymer conjugates. For example, in 2006 Hong reported formation of polyacrylamide biotin conjugate 2 using prefunctionalised RAFT agent 1 (eqn (1)). ${ }^{6 a, 8}$ While this approach provided a biotin polyacrylamide conjugate it retained the thiocarbonylthio endgroup, which is generally considered undesirable as it can lead to instability, discolouration, or unpleasant odours. ${ }^{9}$ An alternate strategy to the formation of polymer conjugates involves post-polymerisation functionalization (Scheme 1b). This often involves a two-step cleavage of the thiocarbonyl group to leave a free thiol, ${ }^{10}$ and coupling via thiol ene or other sulfur specific conjugations (eqn (2)). ${ }^{11}$ This common strategy suffers from its multistep nature while leaving a sulphurcontaining tether, which may be prone to oxidation, elimination or exchange reactions. ${ }^{12} \mathrm{~A}$ number of functionalisations allow removal of the sulfur-containing end-group..$^{13}$ In early studies, thermal eliminations were developed to generate alkene terminated polymers, ${ }^{14}$ while more recently re-initiation and quenching with a hydrogen atom source ${ }^{15}$ or alkyl radical has been developed (eqn (3)). ${ }^{13 b, 16}$ Recently reported desulfurisation to generate bromine terminated polymers has been described by Lunn using a 2 -step aminolysis/bromination, ${ }^{17}$ while Armes used oxidative methods to give hydroxyl end-

${ }^{a}$ School of Chemistry, Monash University, Clayton, Melbourne, VIC 3800, Australia. E-mail: david.lupton@monash.edu; joel.hooper@monash.edu

${ }^{b}$ CSIRO, Research Way, Melbourne, VIC 3168, Australia

$\dagger$ Electronic supplementary information (ESI) available: Experimental details, NMR spectra of all new compounds, GPC traces, MALDI-MS. See DOI: $10.1039 / \mathrm{c} 8 \mathrm{sc} 01862 \mathrm{f}$ groups. ${ }^{18}$ In addition, Lunn and Sumerlin have independently exploited photoactivation to deliver hydrogen terminated polymers. ${ }^{19}$ Although existing techniques to remove sulfur have strengths, they often require multiple reactions and are only capable of introducing simple functionality.

Despite recent advances in the use of transition metals for the activation and functionalisation of C-S bonds, ${ }^{20}$ we noted with interest that this strategy has not been applied to RAFT

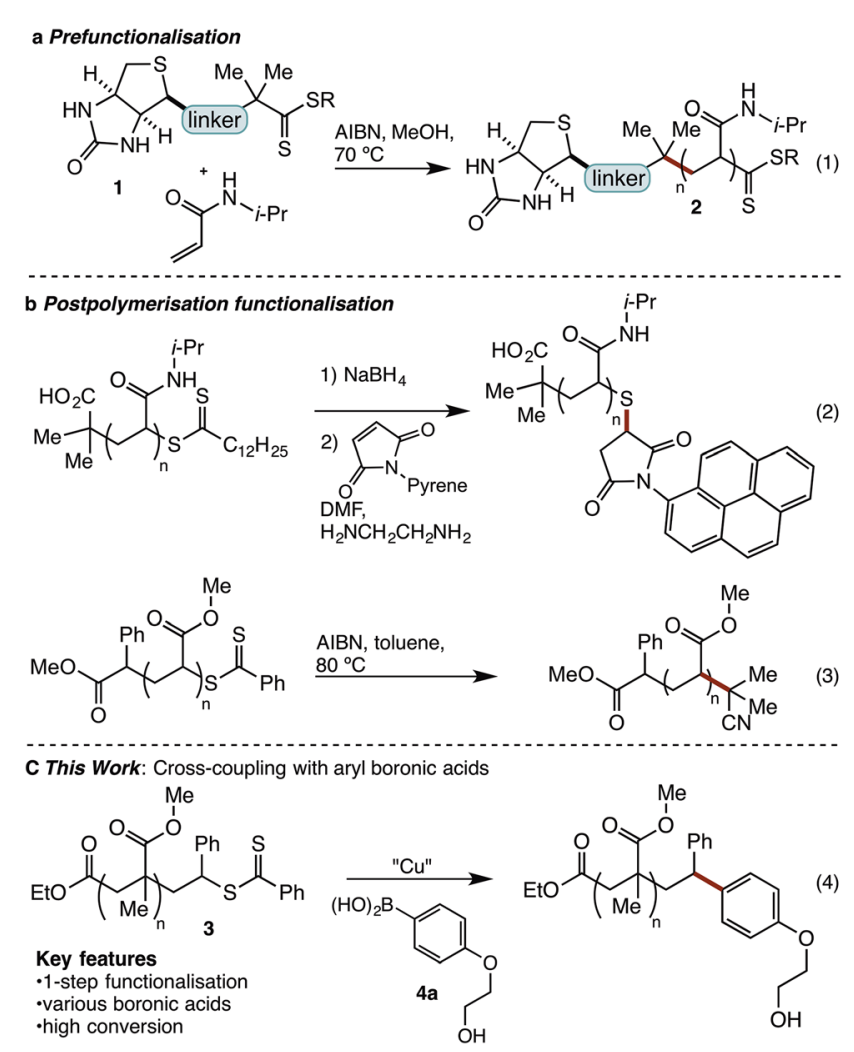

Scheme 1 Existing approaches to RAFT end-group removal. 
endgroups. In principle, such a strategy should allow deletion of the sulfur end-group and introduction of new functionality via a robust $\mathrm{C}-\mathrm{C}$ bond. Herein, we report studies on this topic that have led to the discovery of a $\mathrm{Cu}[\mathrm{II}]$ promoted coupling of RAFT polymers 3 with aryl boronic acid 4 (eqn (4)). This method exploits readily available boronic acids, deletes the thiocarbonylthio group, and introduces the conjugate with a stable $\mathrm{C}-\mathrm{C}$ bond.

\section{Results and discussion}

Studies began by examining the cross-coupling of small molecule polystyrene surrogates (i.e. 5) with aryl boronic acid (4b) (Table 1). Pleasingly a range of $\mathrm{Cu}[0]$ and $[\mathrm{II}]$ complexes gave the desired diarylmethane $\mathbf{6}$, albeit in low yield (Table 1, entries 15). $\mathrm{Cu}\left(\mathrm{BF}_{4}\right)_{2} \cdot \mathrm{H}_{2} \mathrm{O}$ proved the best copper promoter, giving the product in $35 \%$ isolated yield (Table 1, entry 5). Solvent screening identified chlorinated solvents, and particularly 1,2dichloroethane, as suitable for this reaction lifting the yield to $54 \%$ (Table 1, entries 6-10). This outcome was improved with the simpler phenyl-thiocarbonylthio substrate (5b) (Table 1, entry 11). Finally, through attempts to dry the $\mathrm{Cu}\left(\mathrm{BF}_{4}\right)_{2} \cdot \mathrm{H}_{2} \mathrm{O}$ salt over $\mathrm{MgSO}_{4}$ in EtOAc, an amorphous $\mathrm{Cu}\left(\mathrm{BF}_{4}\right)_{2} \cdot \mathrm{H}_{2} \mathrm{O} \cdot$ EtOAc adduct formed that proved more active than the $\mathrm{Cu}\left(\mathrm{BF}_{4}\right)_{2} \cdot \mathrm{H}_{2} \mathrm{O}$ salt, leading to the isolation of diarylmethane 6 in $85 \%$ yield from the coupling of phenyl-thiocarbonylthio $\mathbf{5 b}$ with boronic acid $\mathbf{4 b}$.

With conditions optimised for end-group modification of a polystyrene surrogate, the cross-coupling with a low molecular weight polystyrene bearing a phenyl-thiocarbonylthio endgroup (i.e. 7) was examined (Fig. 1). Pleasingly, the conditions were well suited to polymer 7 and gave the polymer conjugate 8

Table 1 Optimisation of the cross-coupling of thiocarbonylthio 5 with boronic acid 4b

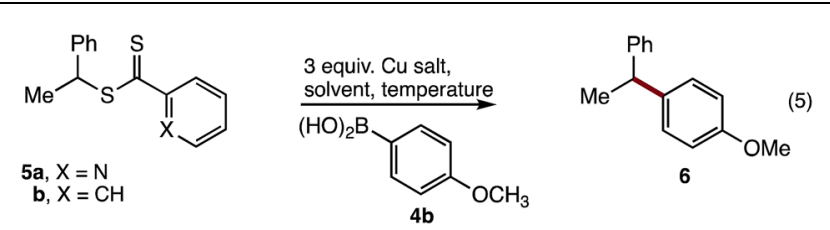

\begin{tabular}{|c|c|c|c|c|c|}
\hline Entry 5 & & Cu salt & Solvent & Temp & Yield $^{a}$ \\
\hline 1 & $\mathbf{a}$ & $\mathrm{Cu}(\mathrm{acac})$ & THF & 66 & 0 \\
\hline 2 & $\prime \prime$ & $\mathrm{CuCl}_{2} \cdot \mathrm{H}_{2} \mathrm{O}$ & $\prime \prime$ & " & Trace \\
\hline 3 & $\prime \prime$ & $\mathrm{Cu}$ powder & $\prime \prime$ & " & 12 \\
\hline 4 & $\prime \prime$ & $\mathrm{Cu}(\mathrm{OAc})_{2} \cdot \mathrm{H}_{2} \mathrm{O}$ & $\prime \prime$ & "I & 21 \\
\hline 5 & " & $\mathrm{Cu}\left(\mathrm{BF}_{4}\right)_{2} \cdot \mathrm{H}_{2} \mathrm{O}$ & $\prime \prime$ & " & 35 \\
\hline 6 & $" \prime$ & " & Dioxane & " & 12 \\
\hline 7 & $\prime \prime$ & " & DMF & $\prime \prime$ & 21 \\
\hline 8 & $\prime \prime$ & " & Toluene & $\prime \prime$ & 16 \\
\hline 9 & $\prime \prime$ & " & $\mathrm{CH}_{2} \mathrm{Cl}_{2}$ & 40 & 42 \\
\hline 10 & $\prime \prime$ & $\prime \prime$ & DCE & 66 & 54 \\
\hline $11^{a}$ & b & $" \prime$ & DCE & 80 & 67 \\
\hline $12^{a}$ & $\mathbf{b}$ & $\mathrm{Cu}\left(\mathrm{BF}_{4}\right)_{2} \cdot \mathrm{H}_{2} \mathrm{O} \cdot$ EtOAc & $\prime \prime$ & 80 & 85 \\
\hline
\end{tabular}

${ }^{a}$ Isolated yields.
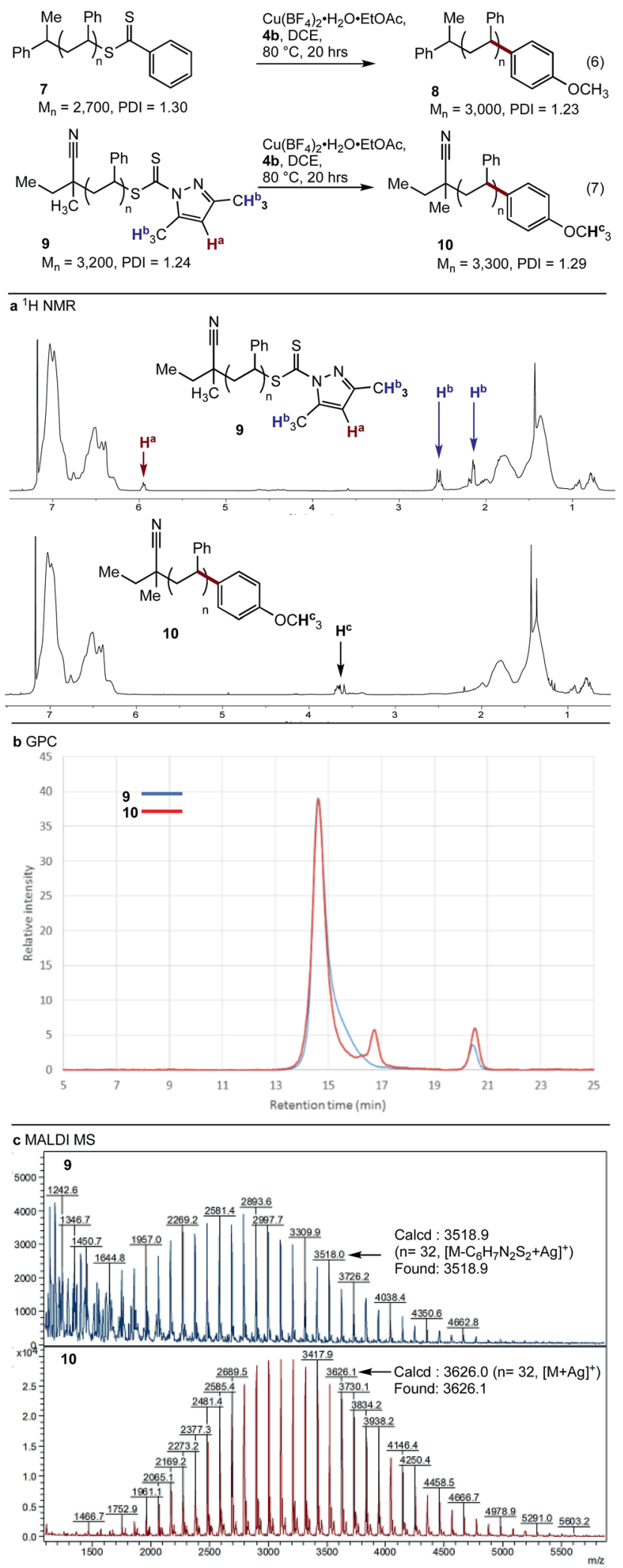

Fig. 1 Cross-coupling of polystyrenes 7 and 9 with boronic acid 4 b.

with $>95 \%$ end-group conversion, as judged by ${ }^{1} \mathrm{H}$ NMR spectroscopy (see ESI $\dagger$ ). The conditions were equally suited (>95\% conversion) to the cross-coupling of polystyrene bearing the 
recently reported dimethylpyrazole end-group (i.e. 9) with aryl boronic acid $\mathbf{4 b}$ (eqn (7)). ${ }^{21}$ The ${ }^{1} \mathrm{H}$ NMR spectra of the resultant conjugate 10 showed clear disappearance of signals assigned to the pyrazole end-group (i.e. $\mathbf{H}^{\mathbf{a}}$ and $\mathbf{H}^{\mathbf{b}}$ ). In addition, a broad signal at $\sim 3.75 \mathrm{ppm}$ was seen, consistent with the methoxy group from the aryl boronic acid (Fig. 1a).

As expected, analysis of polymers $\mathbf{9}$ and $\mathbf{1 0}$ by gel permeation chromatography (GPC) showed very little change in the molecular weight or dispersity (Fig. 1b). MALDI-MS analysis of polymers 9 and 10 clearly showed incorporation of the aryl endgroup (Fig. 1c). Finally, analysis of polymer 10 by ICP-MS after only simple purification by precipitation showed a residual copper content of $<10 \mathrm{ppm}$.

We next tested our coupling conditions on higher molecular weight polystyrenes 11 and 13 (Fig. 2). Coupling under our standard conditions, with 3 equivalents of $\mathrm{Cu}$ relative to the endgroup, resulted in incomplete conversion. However, when the equivalents of $\mathrm{Cu}$ and $\mathbf{4 b}$ were increased so as to maintain the same concentration as in the previous experiments $(\sim 50 \mathrm{mg}$ $\mathrm{mL}^{-1} \mathrm{Cu}\left(\mathrm{BF}_{4}\right)_{2} \cdot \mathrm{H}_{2} \mathrm{O} \cdot$ EtOAc, 16 equiv for $\mathbf{1 1}, 36$ equiv. for 13), clear incorporation of the new methoxyphenyl end-group could be observed. While quantitative end-group analysis by ${ }^{1} \mathrm{H}$ NMR spectroscopy is difficult at these higher molecular weights, these results clearly show that our coupling conditions are viable with these substrates, as long as the concentration of reagents is maintained at the optimised level.

Having established cross-coupling with polystyrene, the applicability of these conditions to the coupling of model polyacrylate (15) and polymethacrylate (16) small molecules with aryl boronic acid $\mathbf{4 b}$ was examined. Unfortunately, these reactions resulted in decomposition of the starting materials
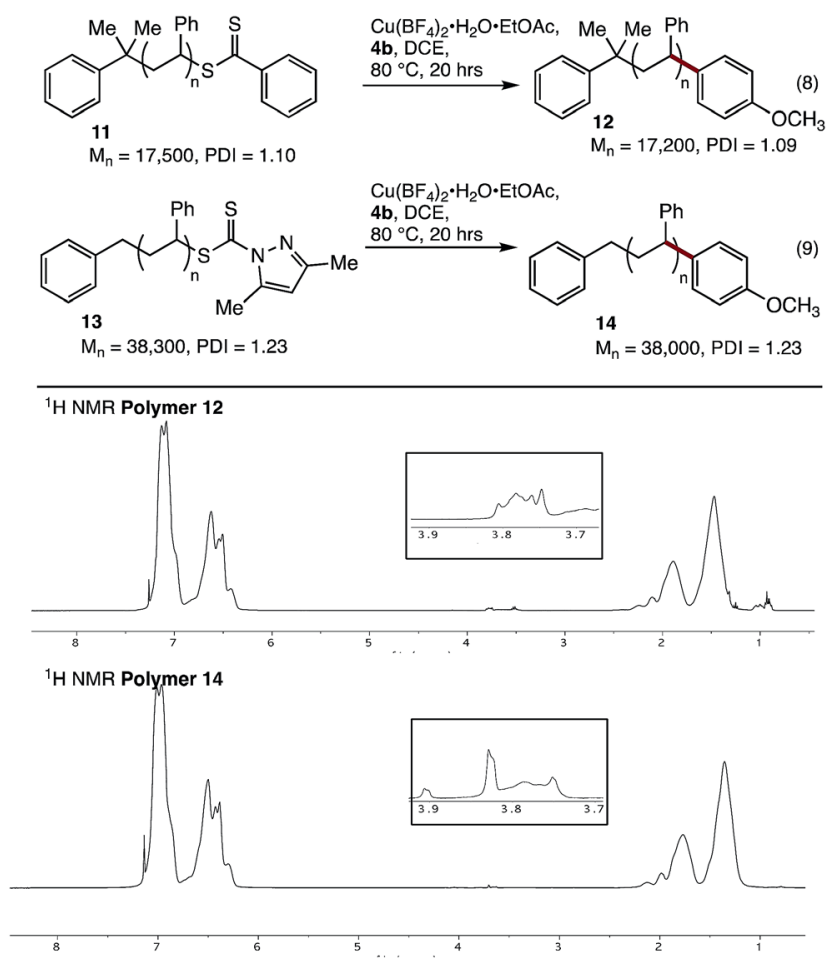

Fig. 2 Cross-coupling of polystyrenes 11 and 13 with boronic acid 4b.

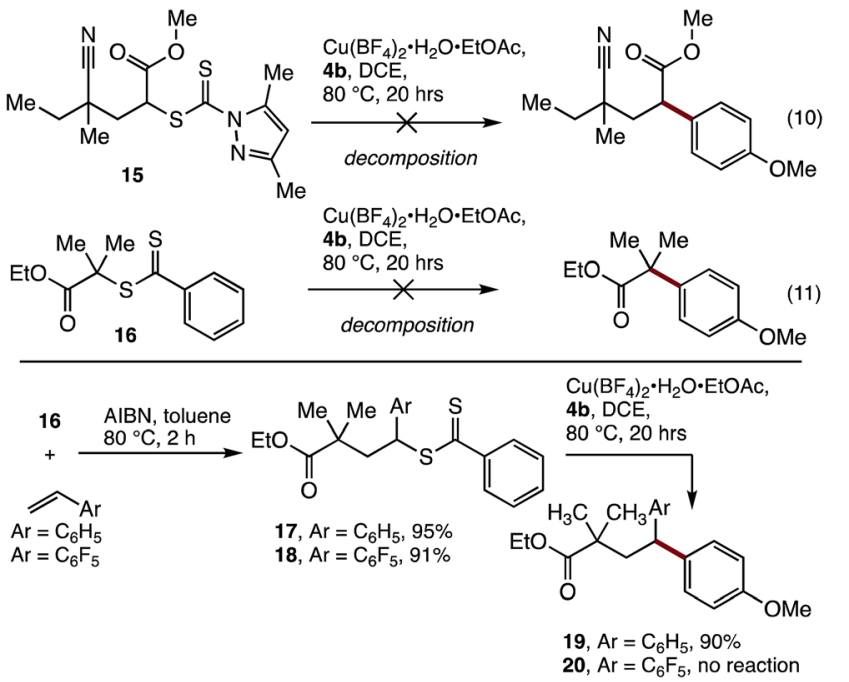

Scheme 2 SUMI/coupling strategy for the modification of methacrylates.

(Scheme 2), indicating that benzylic activation of the reactive site is required for effective coupling.

The requirement for benzylic activation at the reactive site is consistent with previous Cu-promoted activation of $\mathrm{C}_{\mathrm{sp}^{3}-\mathrm{S}}$ bonds, ${ }^{22}$ where benzylic activation is thought to stabilise a proposed carbocation intermediate. In addition, a radicalbased mechanism is also possible, where copper coordination to the dithiocarbonyl group is followed by $\mathrm{C}-\mathrm{S}$ bond clevage to produce a benzylic radical and concomitant single-electron oxidation of $\mathrm{Cu}$. It has been previously shown that $\mathrm{Cu}[0]^{23}$ or $\mathrm{Fe}[0]^{24}$ can be used to initiate RAFT polymerisations, suggesting that $\mathrm{C}_{\mathrm{sp}^{3}}$ radicals can be generated under these conditions.

To address this limitation, we examined the incorporation of styrene units to the end of a polymethacrylate to modify its reactivity. The synthesis of a block co-polymer was considered, although this would complicate the characterisation of the polymer by MALDI-MS, and would limit the utility of the material produced. As an alternative, a single unit monomer insertion (SUMI) ${ }^{25}$ strategy was examined, where a single styrene unit may be inserted into the end of the polymer. This strategy would provide the required reactivity for functionalization and deliver a well-defined material for analysis, while having minimal impact on the bulk properties of the polymethacrylate.

Thus, treatment of the model substrate 16 with AIBN and two equivalents of styrene gave the SUMI surrogate 17 in excellent yield (Scheme 2). The incorporation of pentafluorostyrene was also successful (18), which was included to probe the effect of increased cation/radical stabilisation at the benzylic position. While 18 proved to be unreactive under the cross-coupling conditions, the styrene insertion product 17 underwent efficient coupling with boronic acid $\mathbf{4 b}$ to deliver 19 in $90 \%$ yield. ${ }^{26}$

Having demonstrated the viability of a SUMI strategy to modify the endgroup reactivity of a methacrylate surrogate, this approach was examined with polymethylmethacrylate 21 . Single monomer insertion of styrene gave 22, which underwent 
smooth cross-coupling with boronic acid $\mathbf{4 b}$, to give the endgroup modified polymethacrylate 23. While the aryl methoxy peak was obscured in the ${ }^{1} \mathrm{H}$ NMR spectra of 23, characteristic aryl peaks could be observed at $6.7 \mathrm{ppm}\left(\mathrm{H}^{\mathrm{d}}\right)$, consistent with $>95 \%$ incorporation of the end group. This was further confirmed by MALDI-MS analysis (Fig. 3).

The styrene SUMI strategy was also applied to a larger polymethacrylate $\left(M_{\mathrm{n}}=14600\right)$, to generate polymer 24. Coupling of this material with the ethylene glycol substituted aryl boronic acid $4 \mathbf{a}$ gave the modified polymer 25 (Fig. 4). The ${ }^{1} \mathrm{H}$ NMR spectra clearly shows the endgroups from both the ethyl ester $\left(\mathrm{H}^{\mathrm{d}}\right)$ and the ethylene glycol groups $\left(\mathrm{H}^{\mathrm{e}}\right.$ and $\mathrm{H}^{\mathrm{f}}$, Fig. 4), while ${ }^{1} \mathrm{H}$ DOESY NMR analysis shows that $\mathrm{H}^{\mathrm{e}}$ and $\mathrm{H}^{\mathrm{f}}$ have the same diffusion coefficient $\left(8.4 \times 10^{-11} \mathrm{~m}^{2} \mathrm{~s}^{-1}\right)$ as the bulk polymer, indicating successful incorporation of the aryl boronic acid into the polymer chain.

As a demonstration of the utility of this method, we coupled two highly functional molecules to methacrylate polymers (Fig. 5). Boronic acid 4 a was covalently linked to a BODIPY dye, before coupling with polymer 22 to give the functionalised material 26. UV-vis analysis of the polymer shows a strong absorbance at $490-510 \mathrm{~nm}$, which overlaps well with the absorbance of the BODIPY dye (Fig. 5). A similar strategy was used to synthesise polymer 27 , with a biotin functional group linked to a water soluble polymethacrylate bearing a triethylene glycol methyl ether (TEGOMe) group. Analysis of the ${ }^{1} \mathrm{H}$ NMR spectra of this polymer shows clear signals at 4.13 and $4.40 \mathrm{ppm}$, consistent with the methylene groups of the linker, along with signals at $\sim 6.8 \mathrm{ppm}$ which we assign to the newly introduced aryl-oxy group (see ESI $\dagger$ ).
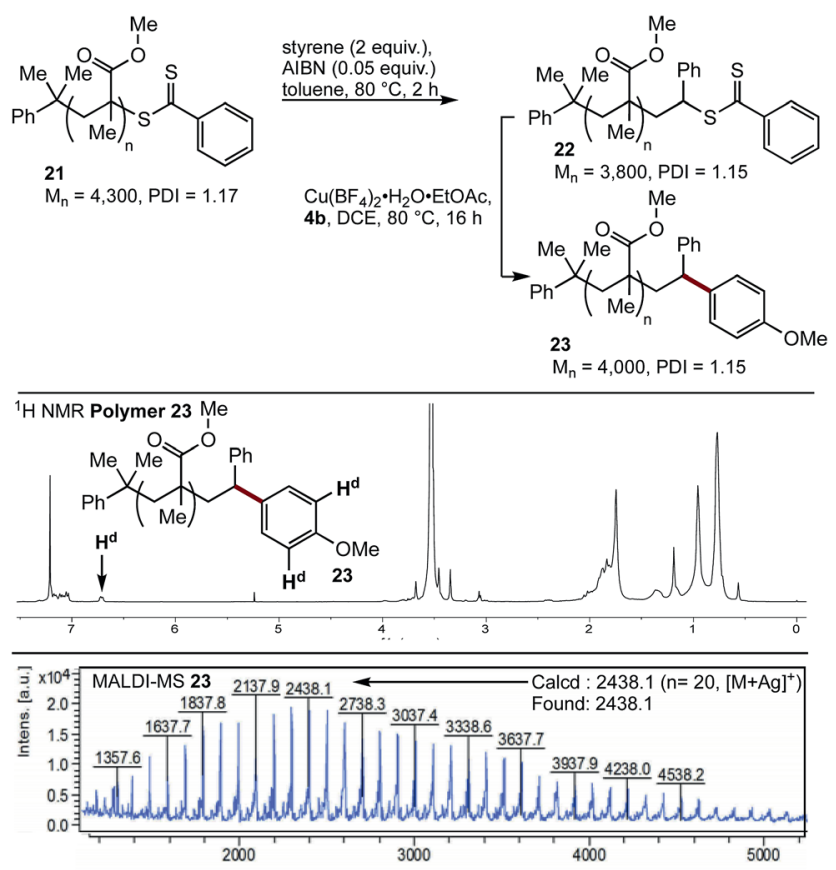

Fig. 3 SUMI/coupling strategy for modification of polymer 22, NMR and MALDI-MS of 23.

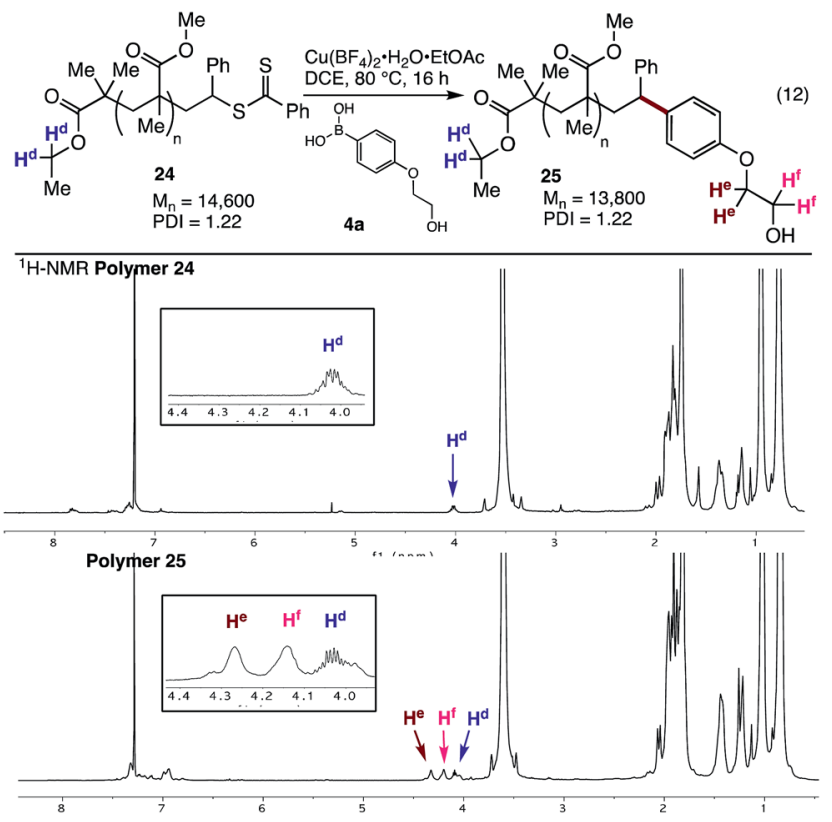

Fig. 4 Cross-coupling with 24 and ${ }^{1} \mathrm{H}$ NMR spectra of polymers 24 and 25 .

The copper-promoted cross-coupling of RAFT polymers with aryl boronic acids is a powerful method to access functionalised polymers with controlled molecular weight and low polydispersity. This methodology has been demonstrated with a variety of polymers, including polystyrenes, and several<smiles></smiles>
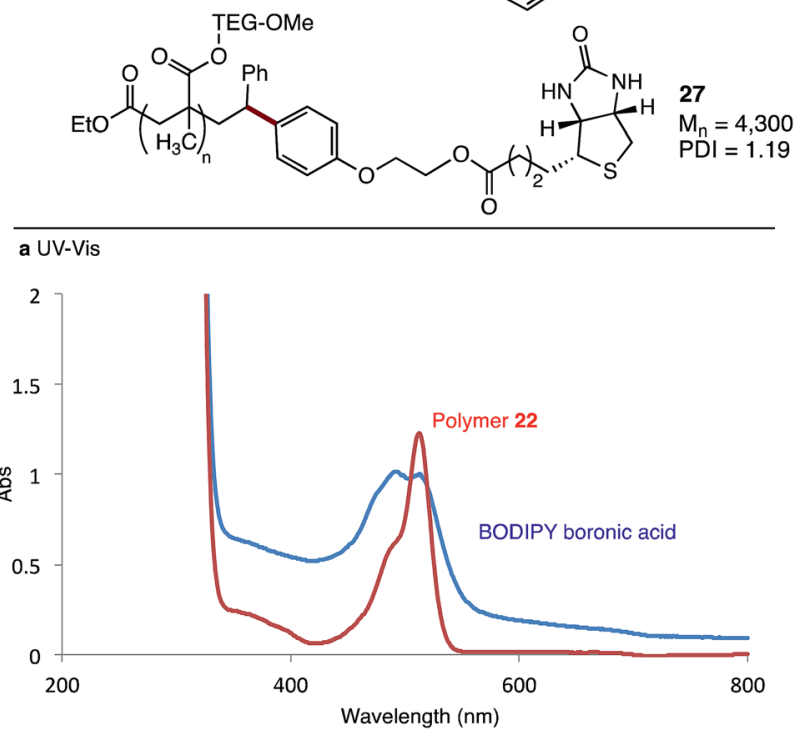

Fig. 5 Polymer functionalisation with complex functional groups. 
polymethacrylates. We believe that this method will aide in the discovery of new polymers for functional materials and biological applications.

\section{Conflicts of interest}

There are no conflicts to declare.

\section{Acknowledgements}

Financial support from the Australian Research Council through the Discovery programs (DWL) and a DECRA fellowship $(\mathrm{JFH})$ is acknowledged. JFH would like to acknowledge valuable advice from Dr Graham Moad (CSIRO), and Professors San Thang and Tanja Junkers (Monash University).

\section{References}

1 (a) J. Chiefari, Y. K. Chong, F. Ercole, J. Krstina, J. Jeffery, T. P. T. Le, R. T. A. Mayadunne, G. F. Meijs, C. L. Moad, G. Moad, E. Rizzardo and S. H. Thang, Macromolecules, 1998，31，5559-5562; (b) G. Moad, E. Rizzardo and S. H. Thang, Aust. J. Chem., 2009, 62, 1402-1472; (c) G. Moad, E. Rizzardo and S. H. Thang, Polymer, 2008, 49, 1079-1131; (d) W. A. Braunecker and K. Matyjaszewski, Prog. Polym. Sci., 2007, 32, 93-146; (e) G. Moad, E. Rizzardo and S. H. Thang, Aust. J. Chem., 2006, 59, 669-692; (f) G. Moad, E. Rizzardo and S. H. Thang, Aust. J. Chem., 2005, 58, 379-410; $(g)$ G. Moad, Y. K. Chong, A. Postma, E. Rizzardo and S. H. Thang, Polymer, 2005, 46, 8458-8468; (h) Y. Zhang, R. A. Mulvenna, S. Qu, B. W. Boudouris and W. A. Phillip, ACS Macro Lett., 2017, 6, 726-732; (i) A. Kerr, M. Hartlieb, J. Sanchis, T. Smith and S. Perrier, Chem. Commun., 2017, 53, 11901-11904; (j) J. JonikaiteSvegzdiene, A. Kudresova, S. Paukstis, M. Skapas and R. Makuska, Polym. Chem., 2017, 8, 5621-5632; (k) C. Boyer, M. H. Stenzel and T. P. Davis, J. Polym. Sci., Part A: Polym. Chem., 2011, 49, 551-595; (l) S. Edmondson, V. L. Osborne and W. T. S. Huck, Chem. Soc. Rev., 2004, 33, 14-22; $(\mathrm{m})$ M. Baum and W. J. Brittain, Macromolecules, 2002, 35, 610-615.

2 (a) J. Hu, R. Qiao, M. R. Whittaker, J. F. Quinn and T. P. Davis, Aust. J. Chem., 2017, 70, 1161-1170; (b) B. D. Fairbanks, P. A. Gunatillake and L. Meagher, $A d v$. Drug Delivery Rev., 2015, 91, 141-152; (c) S. E. York, A. W. York and C. L. McCormick, ACS Symp. Ser., 2010, 1053, 49-63; (d) C. Boyer, V. Bulmus, T. P. Davis, V. Ladmiral, J. Liu and S. Perrier, Chem. Rev., 2009, 109, 5402-5436.

3 (a) S. Bandyopadhyay, X. Xia, A. Maiseiyeu, G. Mihai, S. Rajagopalan and D. Bong, Macromolecules, 2012, 45, 6766-6773; (b) J.-R. Chen, H.-T. Lin, G.-W. Hwang, Y.-J. Chan and P.-W. Li, Nanotechnology, 2009, 20, 255706255709.

4 (a) C. C. Williams, S. H. Thang, T. Hantke, U. Vogel, P. H. Seeberger, J. Tsanaktsidis and B. Lepenies, ChemMedChem, 2012, 7, 281-291; (b) Y. Xiao, R. Xiao,
J. Tang, Q. Zhu, X. Li, Y. Xiong and X. Wu, Talanta, 2017, 162, 415-422; (c) L. Qiu, J.-W. Li, C.-Y. Hong and C.-Y. Pan, ACS Appl. Mater. Interfaces, 2017, 9, 40887-40897; (d) B. Louage, M. J. van Steenbergen, L. Nuhn, M. D. P. Risseeuw, I. Karalic, J. Winne, S. Van Calenbergh, W. E. Hennink and B. G. De Geest, ACS Macro Lett., 2017, 6, 272-276; (e) Y. Bao and J. Nicolas, Polym. Chem., 2017, 8, 5174-5184; $(f)$ B. Louage, L. Nuhn, M. D. P. Risseeuw, N. Vanparijs, R. De Coen, I. Karalic, S. Van Calenbergh and B. G. De Geest, Angew. Chem., Int. Ed., 2016, 55, 1179111796; $(g)$ A. W. York, S. E. Kirkland and C. L. McCormick, Adv. Drug Delivery Rev., 2008, 60, 1018-1036; (h) M. H. Stenzel, Chem. Commun., 2008, 3486-3503.

5 (a) C. Chen, F. Kong, X. Wei and S. H. Thang, Chem. Commun., 2017, 53, 10776-10779; (b) N. Isahak, G. Gody, L. R. Malins, N. J. Mitchell, R. J. Payne and S. Perrier, Chem. Commun., 2016, 52, 12952-12955; (c) R. Chapman, K. A. Jolliffe and S. Perrier, Polym. Chem., 2011, 2, 19561963; (d) J. Hentschel, K. Bleek, O. Ernst, J.-F. Lutz and H. G. Boerner, Macromolecules, 2008, 41, 1073-1075; (e) M. G. J. ten Cate, H. Rettig, K. Bernhardt and H. G. Boerner, Macromolecules, 2005, 38, 10643-10649.

6 (a) C.-Y. Hong and C.-Y. Pan, Macromolecules, 2006, 39, 35173524; (b) M. Bathfield, F. D'Agosto, R. Spitz, M.-T. Charreyre and T. Delair, J. Am. Chem. Soc., 2006, 128, 2546-2547.

7 (a) M. M. Herth, M. Barz, D. Moderegger, M. Allmeroth, M. Jahn, O. Thews, R. Zentel and F. Rosch, Biomacromolecules, 2009, 10, 1697-1703; (b) D. Pissuwan, C. Boyer, K. Gunasekaran, T. P. Davis and V. Bulmus, Biomacromolecules, 2010, 11, 412-420.

8 (a) S. Martens, F. Driessen, S. Wallyn, O. Turunc, F. E. Du Prez and P. Espeel, ACS Macro Lett., 2016, 5, 942-945; (b) M. Chen, K. P. Ghiggino, A. W. H. Mau, E. Rizzardo, W. H. F. Sasse, S. H. Thang and G. J. Wilson, Macromolecules, 2004, 37, 5479-5481; (c) D. S. W. Benoit, S. Srinivasan, A. D. Shubin and P. S. Stayton, Biomacromolecules, 2011, 12, 2708-2714.

9 J. Xu, J. He, D. Fan, W. Tang and Y. Yang, Macromolecules, 2006, 39, 3753-3759.

10 (a) J. Mazzolini, I. Mokthari, R. Briquel, O. Boyron, F. Delolme, V. Monteil, D. Bertin, D. Gigmes, F. D'Agosto and C. Boisson, Macromolecules, 2010, 43, 7495-7503; (b) P. J. Roth, D. Kessler, R. Zentel and P. Theato, J. Polym. Sci., Part A: Polym. Chem., 2009, 47, 3118-3130; (c) P. J. Roth and P. Theato, Polym. Prepr., 2010, 51, 746-747; (d) W. Shen, Q. Qiu, Y. Wang, M. Miao, B. Li, T. Zhang, A. Cao and Z. An, Macromol. Rapid Commun., 2010, 31, 1444-1448.

11 (a) A. B. Lowe, RSC Polym. Chem. Ser., 2013, 6, 28-58; (b) A. B. Lowe, Polym. Chem., 2014, 5, 4820-4870; (c) H. W. Ooi, K. S. Jack, A. K. Whittaker and H. Peng, J. Polym. Sci., Part A: Polym. Chem., 2013, 51, 4626-4636; (d) C. W. Scales, A. J. Convertine and C. L. McCormick, Biomacromolecules, 2006, 7, 1389-1392; (e) J. M. Spruell, B. A. Levy, A. Sutherland, W. R. Dichtel, J. Y. Cheng, J. F. Stoddart and A. Nelson, J. Polym. Sci., Part A: Polym. Chem., 2009, 47, 346-356; (f) M. M. Stamenovic, P. Espeel, 
W. Van Camp and F. E. Du Prez, Macromolecules, 2011, 44, 5619-5630; $(g)$ K. J. Sykes, S. Harrisson and D. J. Keddie, Macromol. Chem. Phys., 2016, 217, 2310-2320; (h) N. Toda, S. Asano and C. F. Barbas, III, Angew. Chem., Int. Ed., 2013, 52, 12592-12596; (i) Y. Wu, Y. Zhou, J. Zhu, W. Zhang, X. Pan, Z. Zhang and X. Zhu, Polym. Chem., 2014, 5, 55465550; (j) Q. Zhang, L. Voorhaar, R. Hoogenboom and G. De Geest Bruno, Macromol. Rapid Commun., 2015, 36, 11771183.

12 (a) S. P. S. Koo, M. M. Stamenovic, R. A. Prasath, A. J. Inglis, F. E. Du Prez, C. Barner-Kowollik, W. Van Camp and T. Junkers, J. Polym. Sci., Part A: Polym. Chem., 2010, 48, 1699-1713; (b) M. H. Stenzel, ACS Macro Lett., 2013, 2, 14-18. 13 (a) G. Moad, E. Rizzardo and S. H. Thang, Polym. Int., 2011, 60, 9-25; (b) S. Perrier, P. Takolpuckdee and C. A. Mars, Macromolecules, 2005, 38, 2033-2036; (c) H. Willcock and R. K. O'Reilly, Polym. Chem., 2010, 1, 149-157.

14 (a) C. H. Hornung, A. Postma, S. Saubern and J. Chiefari, Polymer, 2014, 55, 1427-1435; (b) X. Zhang, J. Jiang and Y. Zhang, J. Appl. Polym. Sci., 2016, 133, 43992; (c) Y. Liu, J. He, J. Xu, D. Fan, W. Tang and Y. Yang, Macromolecules, 2005, 38, 10332-10335.

15 Y. K. Chong, G. Moad, E. Rizzardo and S. Thang, Macromolecules, 2007, 40, 4446-4455.

16 (a) M. Chen, G. Moad and E. Rizzardo, J. Polym. Sci., Part A: Polym. Chem., 2009, 47, 6704-6714; (b) B. J. Kim, S. GivenBeck, J. Bang, C. J. Hawker and E. J. Kramer, Macromolecules, 2007, 40, 1796-1798.

17 I.-H. Lee, E. H. Discekici, S. L. Shankel, A. Anastasaki, J. Read de Alaniz, C. J. Hawker and D. J. Lunn, Polym. Chem., 2017, 8, 7188-7194.

18 C. P. Jesson, C. M. Pearce, H. Simon, A. Werner, V. J. Cunningham, J. R. Lovett, M. J. Smallridge, N. J. Warren and S. P. Armes, Macromolecules, 2017, 50, 182-191.

19 (a) R. N. Carmean, C. A. Figg, G. M. Scheutz, T. Kubo and B. S. Sumerlin, ACS Macro Lett., 2017, 6, 185-189; (b) E. H. Discekici, S. L. Shankel, A. Anastasaki, B. Oschmann, I.-H. Lee, J. Niu, A. J. McGrath, P. G. Clark, D. S. Laitar,
J. Read de Alaniz, C. J. Hawker and D. J. Lunn, Chem. Commun., 2017, 53, 1888-1891.

20 (a) J. F. Hooper, A. B. Chaplin, C. Gonzalez-Rodriguez, A. L. Thompson, A. S. Weller and M. C. Willis, J. Am. Chem. Soc., 2012, 134, 2906-2909; (b) J. F. Hooper, R. D. Young, I. Pernik, A. S. Weller and M. C. Willis, Chem. Sci., 2013, 4, 1568-1572; (c) J. F. Hooper, R. D. Young, A. S. Weller and M. C. Willis, Chem.-Eur. J., 2013, 19, 3125-3130; (d) L. Wang, W. He and Z. Yu, Chem. Soc. Rev., 2013, 42, 599621; (e) L. S. Liebeskind and J. Srogl, J. Am. Chem. Soc., 2000, 122, 11260-11261.

21 J. Gardiner, I. Martinez-Botella, J. Tsanaktsidis and G. Moad, Polym. Chem., 2016, 7, 481-492.

22 G. Picazo, A. Arvalo, S. Bernes and J. J. Garcia, Organometallics, 2003, 22, 4734-4738.

23 Q. Zhang, Z. Zhang, W. Wang, J. Zhu, Z. Cheng, N. Zhou, W. Zhang and X. Zhu, J. Polym. Sci. Part A, 2012, 50, 14241433.

24 Z. Zhang, W. Wang, Z. Cheng, J. Zhu, N. Zhou, Y. Yang, Y. Tu and X. Zhu, Macromolecules, 2010, 43, 7979-7984.

25 (a) J. Vandenbergh, G. Reekmans, P. Adriaensens and T. Junkers, Chem. Sci., 2015, 6, 5753-5761; (b) J. Xu, S. Shanmugam, C. Fu, K.-F. Aguey-Zinsou and C. Boyer, J. Am. Chem. Soc., 2016, 138, 3094-3106; (c) J. Xu, C. Fu, S. Shanmugam, C. J. Hawker, G. Moad and C. Boyer, Angew. Chem., Int. Ed., 2017, 56, 8376-8383.

26 The effect of monomer-type and RAFT agent on end-group reactivity is well established. For example, the range of temperatures required to thermalise RAFT end-group across polybutylacrylate (PBA), Polystyrene (PS), Polymethylmethacrylate (PMMA). See: (a) B. Chong, G. Moad, E. Rizzardo, M. Skidmore and S. H. Thang, Aust. J. Chem., 2006, 59, 755-762; (b) A. Postma, T. P. Davis, R. A. Evans, G. Li, G. Moad and M. S. O'Shea, Macromolecules, 2006, 39, 5293-5306; (c) A. Postma, T. P. Davis, G. Li, G. Moad and M. S. O'Shea, Macromolecules, 2006, 39, 5307-5318. 